\title{
Development of Teaching Materials Based on Problem Based Learning Models to Improve Mathematic Problem Solving Ability of VIII Junior High School
}

\author{
Ahmad Sayudi Mulyono Humantal Banjarnahor,* \\ Mathematics Education, Postgraduate School, State University of Medan \\ Medan, North Sumatra, Indonesia
}

\begin{abstract}
This study aims to determine: (1) Describe the validity, practicality, and effectiveness of teaching materials based on problem-based learning that has been developed towards improving the mathematical problem solving abilities of grade VIII students of Junior High School Muhamadiyah 07 Medan; (2) Describe the improvement of students' mathematical problem solving abilities by using teaching materials based on the developed problem-based learning. Researchers developed teaching materials in the form of lesson plans, LKPD, teacher handbooks and student handbooks using the Dick \& Carey development model. The results showed that: (1) Teaching materials based on problem-based learning in improving students' mathematical problem solving abilities developed had met the criteria of being valid, practical, and effective; (2) Improved mathematical problem solving abilities using teaching materials based on problem-based learning that have been developed seen from the average N-gain value in the first trial and second trial, respectively 0.43 and 0.56 which are in the category moderate.
\end{abstract}

Keywords: Teaching material development, Problem Based Learning, Problem Solving Ability

DOI: $10.7176 / \mathrm{JEP} / 12-16-06$

Publication date:June $30^{\text {th }} 2021$

\section{Introduction}

Education is a process that takes place continuously until students reach adult personalities. This process takes place within a certain period of time. If students have reached an adult personality, then students are fully capable of acting on their own for the welfare of their lives and the surrounding community (Hamalik, 2009: 3) [1]. This can be seen from the phenomenon of society where the educational character of a child who has education is less clear than a child who is sufficiently educated.

Mathematics is a universal science that underlies technological development and has an important role in various scientific disciplines and advances human thinking. Hasratudin (2018: 159) [2] argues that mathematics is a product of human intellectual thinking. Intellectual thinking is usually driven from problems related to everyday real life. In such a way, mathematics is also referred to as human life and a means to train thinking. It turns out that it is not only that, Eviliasani, Hendriana and Sanjayawati (2018: 334) [3] that mathematics is taught basically aims at students' mindset so that they can solve problems and are creative, critical, logical, analytical, systematic, and have the ability to work together.

Cornelius (1982) [4] argues that there are five reasons for the importance of learning mathematics, namely: (1) mathematics is a clear means of thinking, (2) mathematics is a means of solving problems in everyday life, (3) mathematics is a means of recognizing patterns. -the pattern of relationships and generalization of experiences, (4) mathematics is a means to develop creativity, (5) mathematics is a means to increase awareness of cultural development. From some of the quotes above, it can be concluded that mathematics is very important for all students to learn.

But in reality, behind the important role that mathematics plays, mathematics is a subject that is generally considered difficult and unpleasant for students. This makes mathematics like a monster which is a frightening specter for students at school. As stated by Abdurrahman (2012: 202) [5] from various fields of study taught in schools, mathematics is a field of study that is considered the most difficult for students, both those who do not have learning difficulties, and even more so for students who have learning difficulties. The large number of students who perceive mathematics as a difficult subject at every level of education, often causes various problems that have an impact on the low student achievement.

However, to achieve learning objectives, the teacher must be able to design / design valid and effective teaching materials. Teaching materials must be systematically arranged both written and unwritten to create a learning atmosphere that can be mastered by students. Good teaching materials must be able to make it easier for students to understand mathematics material. Teaching materials can be used as a guide for teachers to direct all activities in the learning process and are a means of evaluating the achievement or mastery of learning outcomes. So that the use of teaching materials allows students to learn a competency coherently and systematically. Therefore, with teaching materials, learning activities will be more interesting and provide opportunities for students to learn more independently and make it easier for students to learn each competency that must be 
mastered.

Teaching materials have benefits for teachers, namely saving teachers time in teaching, changing the teacher's role from being a teacher to being a facilitator, and being able to improve the learning process to be more effective and interactive. While teaching materials also have benefits for students, namely: making learning activities more interesting, giving students the opportunity to study independently, and providing convenience in learning every competency that must be mastered. It is based on the above statement that the development of teaching materials is very important for teachers to do with the aim of improving the quality of learning, especially in mathematics. So that teachers must be able to develop their own teaching materials so that they will be able to carry out harmonious, quality, and useful learning for students.

However, the reality in the field with the 2013 curriculum changes in education makes it difficult for some teachers to design and implement mathematics teaching materials. So that the preparation of teaching materials is only carried out for completeness of school administration, not to help the learning process in class (Sihombing, 2017) [6].

The teaching materials made by the teacher also did not meet the valid, practical and effective criteria which resulted in not achieving the desired learning objectives. This shows that the teaching materials made by the teacher have not been able to make students achieve their learning goals, student responses are negative which causes students to be passive in learning, not skilled in solving the given math problems. According to Nieveen (2007) [7] there are criteria in determining the quality of the results of the development of teaching materials, namely: (1) validity (valid); (2) practically (practically); and (3) effectiveness, so that it can be stated that the quality teaching materials meet the three aspects. Validity is obtained from the validation of teaching materials by experts and peers containing validation of content, constructs, and language. Furthermore, practicality means that teaching materials can be applied by the teacher as planned and easily understood by students. While the effectiveness is seen from the results of an authentic assessment which includes an assessment of the learning process and learning outcomes.

The development of problem-solving abilities is one of the focuses in learning mathematics. But in reality, learning mathematics in class has not paid much attention to the development of mathematical problem solving abilities. So that students 'mathematical problem solving abilities are still not optimal, the low ability of students' problem solving is suspected because learning in schools is still teacher-centered, so that teachers dominate the learning activity process in the classroom compared to students, besides that students are rarely given the opportunity to solve problems in dealing problems, and also the exercises that are given are more routine questions so that they do not train students' reasoning power for problem solving. So that the mastery of this competency for students is still low.

Based on the explanation above, the researcher is interested in conducting research with the title "Development of Teaching Materials Based on Problem Based Learning Models to Improve the Mathematical Problem Solving Ability of Class VIII Students of SMP Muhamadiyah 07 Medan"

\section{Methods}

\subsection{Research Pattern}

This research includes development research. In this research, which is developed in the form of learning tools and the necessary instruments. The development process deals with the activities at each development stage.

\subsection{Subject}

The subjects in this study were students of class VIII-1 and VIII-2 of SMP Muhamadiyah 07 Medan in the academic year 2020/2021, each of which consisted of 20 students.

\subsection{Instruments}

The development of teaching materials has instruments in the form of: (i) Learning Implementation Plan; (ii) Student Book; (iii) student worksheets; (iv) problem solving ability test.

\subsection{Data analysis}

The teaching material development model that will be carried out is the Dick \& Carey development model which consists of 10 stages, namely for several reasons, namely: the Dick \& Carey model has been widely used to develop effective tools, every step of the Dick \& Carey model there is feedback or revision., the steps of the Dick \& Carey model are very concise, concise, clear and interconnected with one another and in accordance with the applicable curriculum because it begins with identifying learning objectives.

\section{Results and Discussion}

\section{a) Development of valid, practical, and effective problem-based teaching materials}

The learning model is a general pattern of learning behavior to achieve the expected learning objectives. The 
general pattern of learning behavior in question can describe the activities of teachers and students in realizing learning conditions or environmental systems that cause the learning process to occur.

Furthermore, according to Joyce \& Weil (2014) [8], Vygotsky argues that a learning model is a plan or pattern that can be used to form a curriculum (long-term learning plans), design learning materials, and guide learning in class or others.

Problem-Based Learning is progressive active learning and student-centered learning (Tan, 2004: 7) [9]. In Problem Based Learning, the thinking ability of students is really optimized through a systematic group work process, so that students can empower, hone, test, and develop their thinking skills on an ongoing basis.

The development model that will be used in developing problem-based teaching materials in this study is the Dick \& Carey model developed by Walter Dick \& Lou Carey. Trianto (2010) [10] states that Dick \& Carey shows that there have been many development tools that follow a steady sequence and have succeeded in developing effective teaching materials. Teaching materials developed in this study include Learning Implementation Plans (RPP), Student Books (BS ), Student activity sheets (LKS), tests of mathematical problem solving abilities. All teaching materials developed use problem-based learning. The teaching materials developed are in line with the tools developed by Rahmi (2018), namely RPP, LAS, Teacher Books, Student Books, learning outcomes tests, and self-efficacy questionnaires. There are differences in the tools developed in this study with the teaching materials developed by Rahmi. This difference lies in the teacher's book, that is, the researcher does not develop the teacher's book.

In the development of this teaching material, a validation process was carried out by a validator and statistical validation in the field to meet the requirements of sufficiently good tools. The fulfillment of the validity aspect is in line with the opinion of Akker (1999) [11] which states that validity refers to the extent to which the design of the device is based on the latest state of technology, art or science ('content validity') and the various components of the device are consistently related to one another. others ('construct validity').

Apart from validity, effectiveness is also needed as a requirement for good teaching materials. In this study, 2 indicators of effectiveness were determined, namely the achievement of student learning completeness and student responses. In the first trial, the two indicators had not met the stipulated requirements, while in the second trial the two indicators had met the predetermined criteria. This is in line with Nieeven's (2007) opinion which states that effectiveness refers to the way students experience the curriculum and student achievement outcomes in accordance with the goals set by the developer.

Next is practicality in terms of the evaluation of the validators, the responses of teachers and students as users of teaching materials, and the implementation of teaching materials. While effectiveness is viewed from the completeness of student classical learning outcomes, student positive responses, and the ability of teachers to manage learning.

b) Description of Student's Problem Solving Ability Results Data

Based on the learning completeness criteria, the students' problem-solving abilities in the first trial can be seen in Table 4.1 as follows:

Table 4.1. Level of Completeness of Problem Solving Ability in Trial I and Trial II

\begin{tabular}{|l|c|c|c|c|}
\hline \multirow{2}{*}{ Category } & \multicolumn{2}{|c|}{ Trial I } & \multicolumn{2}{c|}{ Trial II } \\
\cline { 2 - 5 } & Number of students & Percentage & Number of students & Percentage \\
\hline complete & 14 orang & $70 \%$ & 17 orang & $85 \%$ \\
\hline not complete & 6 orang & $30 \%$ & 3 orang & $15 \%$ \\
\hline Total & 20 orang & $100 \%$ & 20 orang & $100 \%$ \\
\hline
\end{tabular}

Based on Table 4.1, it can be seen that in the first trial after learning was carried out using problem-based teaching materials, based on the posttest data obtained that the criteria for student learning completeness were obtained that the number of students who completed learning was 14 out of 20 students $(70 \%)$ of the total number of students. . The number of students who did not complete was 6 out of 20 students (30\%) of the total number of students. Furthermore, it is classified as a classi fi cation that a learning is deemed complete, there are $85 \%$ of students who have taken the test who have achieved a minimum score of 75 . Thus, the post-test results in the first try did not meet the criteria for class completeness. Then in the second trial, it was seen that after learning using problem-based teaching materials, based on the posttest data obtained, the criteria for student learning mastery were obtained that the number of students who had completed learning was 17 out of 20 students $(85.00 \%)$ of the total number of students. The number of students who did not complete was 3 out of 20 students $(10.00 \%)$ of the total number of students. Furthermore, it is classified as a classi fi cation that a learning is considered complete, there are $85 \%$ of students who have taken the test who have reached a minimum score of 75. Thus, the post-test results on the second trial have met the completeness criteria.

c) Description of Increased Problem Solving Ability in Trial I against Trial II

Increasing the problem-solving abilities taught using teaching materials with the application of the problembased learning model as a whole can be seen in table 4.2 
Table 4.2 Improved Problem Solving Ability

\begin{tabular}{|l|c|c|}
\hline & Trial I & Trial II \\
\hline Average value & 80,10 & 84,06 \\
\hline
\end{tabular}

Masalah (Problem Based Learning) dapat dilihat dari nilai rata-rata ujicoba I ke ujicoba II meningkat dari 80,10 menjadi 84,05 .

\section{Conclusions}

1) Teaching materials based on problem-based learning in improving students' mathematical problem solving abilities have met valid criteria, namely 1) RPP validation results validated by a team of experts with a total average of 4.81 in the valid category, 2) validation results of activity sheets problem-based mathematics students with a total average of 4.85 in the valid category, 3) validation of students 'books with a total average of 4.83 in the valid category, and 4) validation of students' mathematical problem solving tests, where the expert team declared valid.

2) Teaching materials based on problem-based learning in improving mathematical problem-solving abilities and student self-efficacy meet practical criteria, namely 1) The response of the expert team or validator which states that teaching materials can be used with minor revisions 2) teachers and students state that the teaching materials are developed can be used easily from the results of the interview, and (3) the implementation of the problem-based teaching materials used has an average implementation of $82.25 \%$ with a good category in trial I.

3) Teaching materials based on problem-based learning in improving students' mathematical problem solving abilities meet the effective criteria, namely 1) classical completeness reaches $85 \%$, which has met the completeness criteria, namely $\geq 85 \%$ of students reach KKM. 2) Student responses to learning obtained an average of above $80 \%$ in trial I and trial II. and 3) the total average ability of teachers to manage learning in trials I and II were 4.19 and 4.24 respectively, which are in the good category.

4) Improved mathematical problem solving abilities using teaching materials based on problem-based learning that have been developed seen from the average $\mathrm{N}$-gain value in the first trial and second trial, respectively 0.43 and 0.56 which are in the medium category.

\section{References}

[1] Hamalik, Oemar. 2009. Perencanaan Pengajaran Berdasarkan Pendekatan Sistem. Jakarta: Bumi Aksara.

[2] Hasratuddin. 2018. Mengapa Harus Belajar Matematika. Medan: Perc Edira.

[3] Eviliasani, Hendriana, Sanjawati. 2018. Analisis Kemampuan Berpikir Kreatif Matematis Ditinjau Dari Kepercayaan Diri Siswa SMP Kelas VIII Di Kota Cimahi Pada Materi Bangun Datar Segi Empat. Bandung: Jurnal Pembelajaran Matematika Inovatif.

[4] Cornelius. (1982). Alasan belajar matrmatika. [Online]. Tersedia: http://linarrahma.blogspot.co.id/2016/09/normal-0-false-false-false-in-x-none-x_29.html?m=1.

[5] Abdurrahman, M. 2012. Pendidikan Bagi Anak Berkesulitan Belajar. Jakarta: Rineka Cipta.

[6] Sihombing, H. 2017. Pengembangan Bahan Ajar dalam Pembelajaran Berbasis Masalah dengan Pendekatan Metakogintif untuk Meningkatkan Kemampuan Berpikir Kreatif dan Koneksi Matematis Siswa. Tesis tidak diterbitkan. Medan: Program Pascasarjana Universitas Negeri Medan..

[7] Nieveen, N. 2007. An Introduction to Educational Design Research. Enschede: Netzodruk.

[8] Joyce, B \& Weil. (2014). Model-model Pengajaran. Edisi 8. Terjemahan A. Fuwaid \& A. Mirza. Yogyakarta: Pustaka Pelajar.

[9] Tan, Seng-Oon. 2004. Enhancing Thinking Through Problem-Based Learning Approaches: International Perspectives. Singapore: Cengange Learning

[10] Trianto. 2010. Mendesain Model Pembelajaran Inovatif-Progresif. Jakarta: PT. Kencana Arends, R.I. 2008b. Learning to Teach, Belajar untuk Mengajar. Edisi Ketujuh. Jidil Dua. Terjemahkan oleh Soedjipto, Helly, P. dan Soedjipto, Sri, M. Yogyakarta: Pustaka Pelajar.

[11] Akker, J, V, D. 1999. Principles and Methods of Development Research. Dalam Plomp, T; Nieveen, N; Gustafson, K; Branch, R.M; dan Van Den Akker, J (eds). Design Approaches and Tools in Education and Training. London: Kluwer Academic Publisher. 